\title{
Characterisation of Clostridium difficile strains by polymerase chain reaction with toxin $A$ - and $B$-specific primers
}

\author{
B. W. WREN, S. R. HEARD, A. I. AL-SALEH and S. TABAQCHALI
}

Department of Medical Microbiology, St Bartholomew's Hospital Medical College, West Smithfield, London EC1A $7 B E$

\begin{abstract}
Summary. A total of 218 Clostridium difficile strains was examined for production of toxin A by ELISA, production of toxin $B$ by a cytotoxin assay and the presence of toxin $A$ and $B$ geneassociated sequences by the polymerase chain reaction (PCR). After saturation amplification with toxin B-specific primers, the characteristic amplification product (591 bp) was detected in all 184 toxigenic strains examined. PCR with toxin A-specific primers gave positive results with all but one of the toxigenic strains. By contrast, PCR with toxin A-and toxin B-specific primers yielded negative results with all 34 non-toxigenic strains tested. This suggests that PCR detection of either the toxin A or B gene is a good indication of toxin production. PCR did not require DNA extraction or hybridisation and was convenient, sensitive and rapid. Toxigenic $C$. difficile could be detected in mixed cultures, suggesting a role for PCR in the identification of toxigenic $C$. difficile in primary culture.
\end{abstract}

\section{Introduction}

Toxigenic strains of Clostridium difficile are the major cause of pseudomembranous colitis and antibiotic-associated colitis and diarrhoea. ${ }^{1}$ Two toxins appear to be involved in disease: toxin $\mathrm{A}$, an enterotoxin with cytotoxic activity; and toxin $\mathrm{B}$, a potent cytotoxin. ${ }^{2}$ The diagnosis of $C$. difficileassociated disease depends on the isolation and identification of the organism or the detection and neutralisation of cytotoxic activity from faecal specimens, or both. Results correlate well with clinical disease, but the cytotoxin assay is costly, the toxin cross-reacts with $C$. sordellii toxin, and some laboratories may lack the required facilities. Recently, a direct faecal ELISA (Meridian Diagnostics, Cincinnati, USA), which also cross-reacts with $C$. sordellii toxin, has been reported to have $84 \cdot 1 \%$ sensitivity compared with cytotoxin assay. ${ }^{3}$ This is a rapid, sensitive but expensive test. Another less costly assay for the presence of toxin A is a latex test (Culturette Brand C.difficile test; Marion Laboratories, Kansas, USA) which has been shown to be non-specific for $C$. difficile and to give a large number of false positive results. ${ }^{4,5}$ More rapid, specific and cost-effective tests for the detection of toxigenic $C$. difficile are needed.

The polymerase chain reaction (PCR) allows sensitive detection of a given DNA sequence even in a complex mixture of molecules and has been used in the

Received 19 March 1992; accepted 17 July 1992. identification of a range of pathogenic organisms. ${ }^{6}$ The decrease in cost of thermostable DNA polymerases may make PCR a cost-effective alternative to traditional diagnostic procedures. A potential drawback of PCR in diagnostic applications is that it detects genotypic rather than phenotypic characteristics, and "silent" genes may give false positive results.

Recently, we described a rapid and sensitive assay for toxigenic $C$. difficile by PCR with boiled extracts. ${ }^{7.8}$ The toxin A-specific oligonucleotide primers used were tandem repeat nucleotide sequences from the toxin A gene, which resulted in a characteristic profile of amplified products that provided an easily interpretable alternative to conventional single-product PCR. ${ }^{7-9}$ Previous reports on PCR-based identification

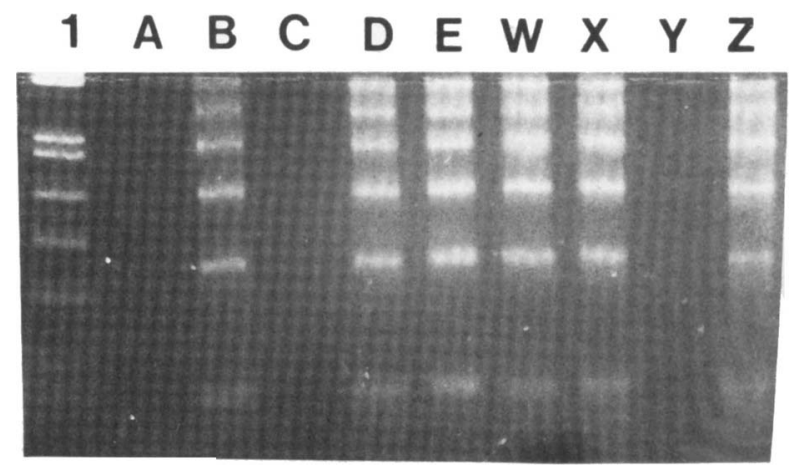

Fig. 1. Identification of toxigenic $C$. difficile with toxin A-specific primers. Lanes $\mathbf{B}, \mathbf{D}, \mathbf{E}, \mathbf{W}, \mathbf{X}$ and $\mathbf{Z}$, toxigenic $C$. difficile strains; $\mathbf{A}$, $\mathbf{C}$ and $\mathbf{Y}$, non-toxigenic $C$. difficile strains; 1, DNA size markers (Bsh 1 and $M s p 1$ digests of pHC314). 
of $C$. difficile have used other toxin A- and B-specific primers or $16 \mathrm{~S}$ rRNA-specific primers, ${ }^{10-12}$ but examined only a limited number of strains. The aim of this study was to determine whether the detection of toxin $A$ and toxin B gene fragments by $P C R$ is a reliable indicator of toxin production in a large number of C. difficile strains from nine distinct typing groups. ${ }^{13}$ Detection of toxigenic $C$. difficile by PCR was also evaluated in mixed culture with a view to developing an alternative method for the detection of toxigenic $C$ difficile.

\section{Materials and methods}

\section{Bacterial strains}

C. difficile strains (218) were cultured anaerobically at $37^{\circ} \mathrm{C}$ on Cycloserine-Cefoxitin-Fructose Agar (Oxoid) and identified by Gram's stain, smell, colony morphology and their characteristic pattern of volatile fatty acid production. ${ }^{14}$ Strains were typed by $\left[{ }^{35} \mathrm{~S}\right]-$ methionine-labelled SDS-PAGE protein profiles (table I). ${ }^{13}$ Twenty strains representing 18 other Clostridium spp. (table II) were cultured on Columbia Horse Blood agar (Oxoid) and identified by standard procedures. ${ }^{14}$ Two streptococcal strains were identified by the API Strep system (API system, Montalieu Vercieu, France).

\section{Toxin assays}

C. difficile strains were cultured in Robertson's Cooked Meat Medium (Southern Group Laboratories, London) at $37^{\circ} \mathrm{C}$ for 3 days and stored at room temperature for subsequent toxin assay. Toxin A was measured quantitatively by ELISA. ${ }^{15}$ Toxin $\mathrm{B}$ was detected by a cytotoxin assay, after pre-incubation with excess antibody to toxin $\mathrm{A}^{{ }^{16}}$

\section{Preparation of PCR samples}

Two or three colonies were suspended in $200 \mu \mathrm{l}$ of sterile water, boiled for $10 \mathrm{~min}$ and centrifuged at $14000 \mathrm{~g}$ for $5 \mathrm{~min} ; 2 \mu \mathrm{l}$ of supernate was used for PCR analysis of bacterial samples.

\section{PCR assay}

The toxin A primers (5'-GAAGCAGCTACTGGATGGC and 5'-AGCAGTGTTAGTATTAAAG) and toxin $\mathrm{B}$ primers (5'-AAGGTTTATATGGATGAT and 5'-TACAACTTTATTAACACAACT), were synthesised on an Applied Biosystems synthesiser by the automated phosphoramidite coupling procedure. For PCR reactions, $2 \mu$ l of the supernate from the boiled sample was added to $50 \mu \mathrm{l}$ of $10 \mathrm{~mm}$ Tris$\mathrm{HCl}$ ( $\mathrm{pH} 8.3$ ) containing $1.5 \mathrm{mM} \mathrm{MgCl}_{2}$ gelatin $0.01 \%$, $200 \mu \mathrm{M}$ each of dATP, dCTP, dGTP and dTTP, 100 pM oligonucleotide primers and 1.5 U Taq polymerase
(Amersham International). The reaction mixture was overlaid with paraffin oil $(50 \mu 1)$, placed in a thermal cycler (Model 2; Hybaid Ltd, Twickenham, Middlesex) and amplified for 30 cycles of $94^{\circ} \mathrm{C}(45 \mathrm{~s}), 46^{\circ} \mathrm{C}$ $(45 \mathrm{~s})$ and $72^{\circ} \mathrm{C}(15 \mathrm{~s})$ for toxin $\mathrm{A}$ and for 40 cycles of $94^{\circ} \mathrm{C}(45 \mathrm{~s}), 40^{\circ} \mathrm{C}(45 \mathrm{~s})$ and $72^{\circ} \mathrm{C}(45 \mathrm{~s})$ for toxin $\mathrm{B}$. The first $94^{\circ} \mathrm{C}$ step was extended to $3 \mathrm{~min}$ to ensure denaturation of the sample. After amplification, the products $(25 \mu \mathrm{l})$ were electrophoresed in a horizontal agarose $1.5 \%$ gel containing ethidium bromide $0.5 \mu \mathrm{g} \mathrm{ml}$ and the bands were visualised under ultraviolet light. All PCR analyses were performed in duplicate with positive $(C$. difficile strain W1) and negative (no organism) controls.

PCR assay of mixed cultures and assessment of assay sensitivity

A single $C$. difficile $\mathrm{W} 1$ or $C$. sporogenes NCTC 532 colony was picked, serially diluted in Wilkins Chalgren Broth (Oxoid) and spread on the surface of blood agar plates for incubation at $37^{\circ} \mathrm{C}$ under anaerobic conditions for $36 \mathrm{~h}$ to determine the viable count. Known quantities of toxigenic $C$. difficile and $C$. sporogenes were mixed and used as samples in PCR experiments.

\section{Results}

\section{$P C R$ with toxin $A$ primers}

Fig. 1 shows PCR results obtained with the tandem repeat sequence toxin A-specific primers. Amplification products appeared as a ladder of bands at multiples of the 63-bp unit length for the toxinproducing strains of SDS-PAGE groups B, D, E, W, X and $Z$. In contrast, no amplification products were observed from the non-toxigenic strains of SDSPAGE groups A, C and Y. Of the 184 toxigenic strains examined, only one was PCR-negative (table I), and this anomalous strain (strain 8864) also gave negative results in the ELISA for toxin A (table I).

\section{$P C R$ with toxin $B$ primers}

Fig. 2 shows PCR results obtained with the toxin Bspecific primers based on a non-repeating region of the toxin $\mathrm{B}$ gene. ${ }^{17} \mathrm{~A}$ single amplified product of expected size $(591 \mathrm{bp})$ was observed with toxin-producing strains of SDS-PAGE groups B, D, E, W, X and Z. In contrast, no amplification products were found from the non-toxigenic strains of SDS-PAGE groups A, C and $Y$. All 184 cytotoxigenic strains yielded the characteristic 591-bp product, but strain 8864 also yielded a product of $c .690 \mathrm{bp}$.

\section{Other bacterial species}

Eighteen other clostridial species were tested for toxin A and B gene sequences by PCR. Toxin B- 
Table I. Results of tissue culture, ELISA and PCR-based toxin analyses of typed C. difficile stains

\begin{tabular}{|c|c|c|c|c|c|c|c|c|c|}
\hline \multirow{3}{*}{ Type } & \multirow{3}{*}{$\begin{array}{c}\text { Number of } \\
\text { strains } \\
\text { examined }\end{array}$} & \multirow{2}{*}{\multicolumn{2}{|c|}{$\begin{array}{l}\text { ELISA result } \\
\text { (toxin } \mathrm{A})\end{array}$}} & \multirow{2}{*}{\multicolumn{2}{|c|}{$\begin{array}{l}\text { Tissue culture result } \\
\text { (toxin B) }\end{array}$}} & \multicolumn{4}{|c|}{ PCR result } \\
\hline & & & & & & \multicolumn{2}{|c|}{ toxin $\mathrm{A}$} & \multicolumn{2}{|c|}{ toxin $B$} \\
\hline & & + & - & + & - & + & - & + & - \\
\hline A & 6 & 0 & 6 & 0 & 6 & 0 & 6 & 0 & 6 \\
\hline B & $* 17$ & 16 & 1 & 17 & 0 & 16 & 1 & 17 & 0 \\
\hline $\mathrm{C}$ & 5 & 2 & 3 & 2 & 3 & 2 & 3 & 2 & 3 \\
\hline $\mathrm{D}$ & 7 & 4 & 3 & 4 & 3 & 4 & 3 & 4 & 3 \\
\hline$E$ & 23 & 23 & 0 . & 23 & 0 & 23 & 0 & 23 & 0 \\
\hline $\overrightarrow{\mathrm{W}}$ & 2 & 2 & 0 & 2 & 0 & 2 & 0 & 2 & 0 \\
\hline $\mathrm{X}$ & 140 & 135 & 5 & 135 & 5 & 135 & 5 & 135 & 5 \\
\hline $\mathbf{Y}$ & 17 & 0 & 17 & 0 & 17 & 0 & 17 & 0 & 17 \\
\hline $\bar{Z}$ & 1 & 1 & 0 & 1 & 0 & 1 & 0 & 1 & 0 \\
\hline Total & 218 & 183 & 35 & 184 & 34 & 183 & 35 & 184 & 34 \\
\hline
\end{tabular}

*Includes one anomalous toxin A negative, toxin B positive strain.

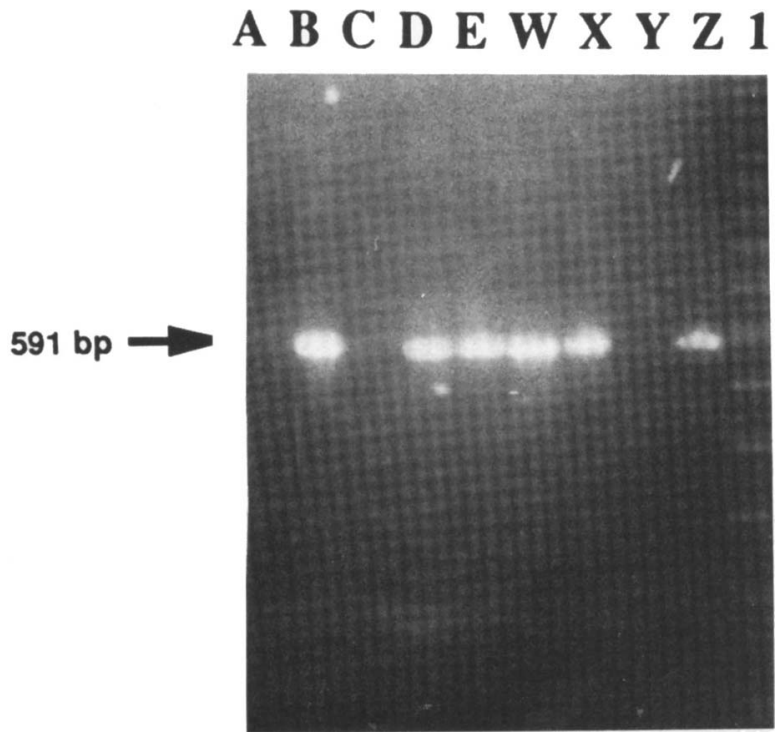

Fig. 2. Identification of toxigenic $C$. difficile with toxin B-specific primers Lanes $\mathbf{B}, \mathbf{D}, \mathbf{E}, \mathbf{W}, \mathbf{X}$ and $\mathbf{Z}$, toxigenic $C$. difficile strains; $\mathbf{A}$, $\mathbf{C}$ and $\mathbf{Y}$, non-toxigenic $C$. difficile strains; $\mathbf{M}$, DNA size markers (100-bp ladder).

specific primers failed to amplify DNA from all nondifficile species tested, but PCR with toxin A-specific primers yielded amplification products from two toxigenic strains of $C$. sordellii (table II). Two strains representing $S$. mutans and $S$. downei, that are known to produce proteins similar to toxins $A$ and $B,{ }^{18}$ gave negative results in PCR with both primer sets (table II).

\section{Sensitivity of PCR}

Sensitivity was determined by assay of serial dilutions of a suspension of $C$. difficile W1. Characteristic amplification products remained detectable with as few as $20 \mathrm{cfu}$ of toxigenic bacteria (toxin A) or $50 \mathrm{cfu}$ of toxigenic bacteria (toxin B)/PCR sample (table III). This level of sensitivity was maintained in a
Table II. Results of PCR-based analyses of non-difficile clostridium spp. and streptococci

\begin{tabular}{|c|c|c|}
\hline \multirow{2}{*}{ Strain* } & \multicolumn{2}{|c|}{ PCR result } \\
\hline & Toxin A & Toxin B \\
\hline C. beijerinckii NCTC 11920 & - & - \\
\hline C. butyricum NCTC 7423 & - & - \\
\hline C. carnis NCTC 10913 & - & - \\
\hline C. chauvoei NCTC 8070 & - & - \\
\hline C. fallax $\mathrm{R} 2720$ & - & -- \\
\hline C. histolyticum NCTC 1503 & - & - \\
\hline C. innocuum R657 & - & - \\
\hline C. novyi type A NCTC 538 & - & - \\
\hline C. paraputrificum NCTC 11823 & - & - \\
\hline C. perfringens NCTC 1265 & - & - \\
\hline C. putrefaciens NCTC 9836 & - & - \\
\hline C. septicum NCTC 547 & - & - \\
\hline C. sordellii NCTC 6800 & + & - \\
\hline C. sordellii NCTC 8780 & + & - \\
\hline C. sphenoides NCTC 507 & - & -- \\
\hline C. sporogenes NCTC 532 & - & - \\
\hline C. tertium NCTC 541 & - & - \\
\hline C. tetani NCTC 540 & - & - \\
\hline C. tetanomorphum NCTC 548 & - & - \\
\hline S. downei $\mathrm{MFe} 28$ & - & - \\
\hline S. mutans GS-5 & - & - \\
\hline
\end{tabular}

*NCTC strains were obtained from the National Collection of Type Cultures, Public Health Laboratory Service, Colindale. C. fallax R2720 and C. innocuum R657 were obtained from M. Phillips, Public Health Laboratory, Luton. The streptococcal strains were provided by R. R. B. Russell, Department of Oral Microbiology, University of Newcastle upon Tyne.

mixed culture containing $10^{7} \mathrm{cfu}$ of $C$. sporogenes NCTC 532/PCR sample (table III).

\section{Discussion}

This study demonstrated that PCR with primers based on either toxin gene sequence can be used as a rapid method to confirm the toxigenic potential of $C$. difficile strains. No false positive PCR results were obtained with 34 non-toxigenic $C$. difficile strains, 
Table III. Sensitivity of PCR with toxin A- and B-specific primers for the detection of toxigenic $C$. difficile

\begin{tabular}{|c|c|c|c|c|}
\hline \multirow[b]{2}{*}{$\begin{array}{c}\text { Viable counts of } \\
\text { C. difficile } \\
\text { (cfu/sample) }\end{array}$} & \multicolumn{4}{|c|}{ PCR results with } \\
\hline & $\begin{array}{l}\text { Toxin A } \\
\text { primers }\end{array}$ & $\begin{array}{l}\text { Toxin B } \\
\text { primers }\end{array}$ & $\begin{array}{l}\text { Toxin a primers } \\
\text { with } C \text {. difficile } \\
\text { in the presence } \\
\text { of } 10^{\frac{7}{7}} \text { cfu of } \\
C \text {. sporogenes } / \\
\text { sample }\end{array}$ & $\begin{array}{l}\text { Toxin B primers } \\
\text { with } C \text {. difficile in } \\
\text { in the presence } \\
\text { of } 10^{7} \text { cfu of } \\
\text { C. sporogenes } / \\
\text { sample }\end{array}$ \\
\hline 5 & - & - & - & - \\
\hline 10 & $+1-^{*}$ & - & - & - \\
\hline 20 & + & - & + & - \\
\hline 50 & + & + & + & + \\
\hline 100 & + & + & + & + \\
\hline
\end{tabular}

*Some bands partially visible.

suggesting that "silent" toxin genes are not present among these strains. Among the 218 toxigenic strains tested by ELISA and tissue culture analysis, 217 were PCR positive with toxin A-specific primers and all gave positive results with the toxin B-specific primers. The anomalous strain (strain 8864) was cytotoxic, but did not produce toxin $\mathrm{A}$; this strain has been described elsewhere. ${ }^{19}$ Recently, McMillen et al. ${ }^{10}$ described PCR analysis of $47 C$. difficile strains with a different set of toxin A- and B-specific primers. From their survey, a single anomalous strain was PCR positive with both sets of primers, but was not cytotoxic under the conditions tested. ${ }^{10}$ These studies demonstrate the usefulness of PCR in identifying toxigenic $C$. difficile and mutations at the two toxin loci.

This study confirms that most $C$. difficile strains appear to produce either both toxins or neither toxin. ${ }^{16}$ The toxin B gene is located only $1.4 \mathrm{~kb}$ upstream of the toxin $\mathrm{A}$ gene ${ }^{20}$ and co-regulation of the two toxins has been observed in a large number of $C$. difficile strains, ${ }^{16}$ suggesting that the toxin genes form a transcription unit. Previously we have shown that DNA from nontoxigenic $C$. difficile strains fails to hybridise with a $4.5-\mathrm{kb}$ toxin $\mathrm{A}$ gene-specific probe, suggesting that these strains lack at least $4.5 \mathrm{~kb}$ of the toxin A gene. ${ }^{21}$ The absence of PCR products from non-toxigenic strains reported here suggests that these strains have a large deletion extending across both toxin genes. It was noticeable that non-toxigenic strains were predominantly SDS-PAGE typing groups $\mathrm{A}$ or $\mathrm{Y}$, and these may represent a distinct sub-species of $C$. difficile.
The use of the tandem repeat sequence toxin Aspecific primers in PCR has two advantages over the toxin B-primers. First, a characteristic profile of bands is amplified from the tandem repeat primers providing a more easily interpretable result. Secondly, the toxin A-specific primers give a PCR assay at least two and a half times more sensitive than the toxin B-specific primers. In contrast to the non-repeat toxin B primers, toxin A primers amplified DNA from toxigenic strains of $C$. sordellii. However, this cross-reaction probably results from shared genetic sequences, rather than being intrinsic to the tandem sequence primer design.

The PCR assay for the identification of toxigenic $C$. difficile described here is rapid, sensitive and requires minimum specimen preparation. Results could be obtained within $3 \mathrm{~h}$ of primary isolation and PCR was successful even in mixed culture with $C$. sporogenes. Gumerlock et al. have described a method for the isolation of $C$. difficile DNA from human stool specimens and were able to detect $C$. difficile from these samples with 16S rRNA-specific primers. ${ }^{12}$ However, they were unable to distinguish between toxigenic and non-toxigenic strains. The use of the toxin-specific primers described in this study coupled with the preparation method described by Gumerlock et al. ${ }^{12}$ could provide a cost-effective PCR-based method for the direct detection of toxigenic $C$. difficile from human faeces.

We thank Dr S. P. Borriello for C. difficile strain 8864. This work was supported by the Wellcome Trust.

\section{References}

1. Bartlett JG, Chang TW, Gurwith M, Gorbach SL, Onderdonk AB. Antibiotic associated pseudomembraneous colitis due to toxin-producing clostridia. N Engl J Med 1978; 298: $531-534$.

2. Taylor NS. Thorne GM. Bartlett JG. Comparison of two toxins produced by Clostridium difficile. Infect Immun 1981; 34: $1036 \quad 1043$.

3. Dipersio JR. Varga FJ, Conwell DL, Kraft JA, Kozak KJ, Willis DH. Development of a rapid enzyme immunoassay for Clostridium difficile toxin $\mathrm{A}$ and its use in the diagnosis

of C. difficile-associated disease. J Clin Microbiol 1991; 29 $2724-2730$.

4. Lyerly DM, Wilkins TD. Commercial latex test for Clostridium difficile toxin A does not detect toxin A. J Clin Microbiol $1986 ; 23: 622-623$.

5. Bennett RG, Laughon BE, Mundy LM et al. Evaluation of a latex agglutination test for Clostridium difficile in two nursing home outbreaks. I Clin Microbiol 1989; 27: 889-893.

6. Pallen MJ, Butcher PD. New strategies in microbiological diagnosis. J Hosp Infect 1991; 18 Suppl A : 147-158.

7. Wren BW, Clayton CL, Tabaqchali S. Nucleotide sequence of 
Clostridium difficile toxin A gene fragment and detection of toxigenic strains by polymerase chain reaction. FEMS Microbiol Lett 1990; 70: 1-6.

8. Wren BW, Clayton CL, Tabaqchali S. Rapid identification of toxigenic Clostridium difficile by polymerase chain reaction. Lancet 1990; 1: 423.

9. Wren BW, Pallen M, Tabaqchali S. Beneficial effects of jumping PCR in diagnostic procedures. Lancet 1990; 1: 1540.

10. McMillin DE, Muldrow LL, Leggette SJ, Abdulahi Y, Ekanemesang UM. Molecular screening of Clostridium difficile toxins $\mathrm{A}$ and $\mathrm{B}$ genetic determinants and identification of mutant strains. FEMS Microbiol Lett 1991; 78: 75-80.

11. Kato $\mathrm{N}$, Ou C, Kato $\mathrm{H}$ et al. Identification of toxigenic Clostridium difficile by the polymerase chain reaction. $J$ Clin Microbiol 1991; 29: 33-37.

12. Gumerlock PH, Tang YF, Meyers FJ, Silva J. Use of the polymerase chain reaction for the specific and direct detection of Clostridium difficile in human faeces. Rev Infect Dis 1991; 13: 1053-1060.

13. Tabaqchali S, O'Farrell S, Holland D, Silman R. Typing scheme for Clostridium difficile; its application in clinical and epidemiological studies. Lancet 1984; 1: 935-938.

14. Holdeman LV, Cato EP, Moore WEC. Anaerobe laboratory manual, 4th edn. Blacksburg, Virginia Polytechnic and State University. 1977.
15. Redmond SC, Ketley JM, Mitchell TJ, Stephen J, Burdon DW, Candy DCA. Detection of Clostridium difficile enterotoxin. In: Collins $\mathbf{C H}$, Grange JM (eds) Isolation and identification of microorganisms of medical and veterinary importance. London, Academic Press. 1985: 237-250.

16. Wren BW, Heard SR, Tabaqchali S. Association between production of toxins A and B and types of Clostridium difficile. J Clin Pathol 1987; 40: 1397-1401.

17. Barroso LA, Wang S-Z, Phelps CJ, Johnson JL, Wilkins TD. Nucleotide sequence of Clostridium difficile toxin B gene. Nucleic Acids Res 1990; 18: 4004.

18. Wren BW. A family of clostridial and streptococcal ligandbinding proteins with conserved C-terminal repeat sequences. Mol Microbiol 1991; 5: 797-803.

19. Borriello SP, Wren BW, Hyde S, Seddon SV et al. Molecular, immunological and biological characterisation of a toxin A-negative toxin B-positive strain of Clostridium difficile. Infect Immun 1992; 60: 4192-4199.

20. Dove $\mathrm{CH}$, Wang S-Z, Price SB et al. Molecular characterization of the Clostridium difficile toxin A gene. Infect Immun 1990; 58: $480-488$.

21. Wren BW, Clayton CL, Castledine NB, Tabaqchali S. Identification of toxigenic Clostridium difficile strains by using a toxin A gene-specific probe. J Clin Microbiol 1990; 28: 1808-1812. 